\title{
Using Health Belief Model for predicting COVID-19 prevention practices among university student and staff
}

\author{
Hidayati Hidayati $^{1}$, Nia Musniati ${ }^{1}$, Ahmad Hidayat ${ }^{2}$, Mochamad Iqbal Nurmansyah ${ }^{3}$ \\ ${ }^{1}$ Department of Public Health, Faculty of Health Sciences, Universitas Muhammadiyah Prof. Dr. Hamka, Jakarta, Indonesia \\ ${ }^{2}$ Department of Health Promotion, Faculty of Public Health, Universitas Andalas, Padang, Indonesia \\ ${ }^{3}$ Department of Public Health, Faculty of Health Sciences, Universitas Islam Negeri Syarif Hidayatullah Jakarta, Banten, Indonesia
}

\begin{abstract}
Article Info
Article history:

Received Jun 9, 2021

Revised Oct 23, 2021

Accepted Nov 7, 2021

\section{Keywords:}

COVID-19 pandemic

Cues to action

Health motivation

Perceived barriers

Perceived benefits

Prevention behavior

ABSTRACT

Large-scale social restriction (PSBB-Pembatasan Sosial Berkala Besar) is a policy aimed at reducing the spread of coronavirus disease 2019 (COVID-19). The purpose of this study was to determine the respondents' compliance behaviors towards the PSBB regulations according to the Health Belief Model. This cross-sectional study was conducted at a private university in Jakarta using quantitative methods. Data collection was carried out on July 2020, where 116 respondents were selected and recruited in the study using convenience non-probability sampling. Online self-administered questionnaire was used to collect data. The independent variables were adopted from Health Belief Model theory. These included; perceived susceptibility, perceived severity, health motivation, perceived benefit, perceived barrier and cues to action. The dependent variable was COVID-19 prevention behavior. Results showed that variables of health motivation ( $\mathrm{p}$-value $=0.001)$, perceived benefits $(\mathrm{p}$-value $=0.008)$, and perceived barriers $(p$-value $=0.007)$, advertising $(p$-value $=0.027)$, counseling $(p$-value $=0.001)$, and media access ( $\mathrm{p}$-value $=0.000$ ) had significant effects on the respondents' compliance to COVID-19 prevention behaviors. Multivariate analysis showed significant association of health motivation and perceived benefits with COVID-19 prevention behavior. An intervention is required to improve the community's perception and belief towards the benefits and effectiveness of COVID-19 prevention behavior in preventing the COVID-19 pandemic.
\end{abstract}

This is an open access article under the CC BY-SA license.

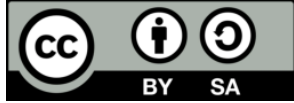

\section{Corresponding Author:}

Hidayati Hidayati

Department of Public Health Faculty of Health Sciences, Universitas Muhammadiyah Prof. Dr. Hamka

Limau II Road, South Jakarta 12130, Indonesia

Email: hidayati@uhamka.ac.id

\section{INTRODUCTION}

On March 2020, the World Health Organization (WHO) declared the Corona Virus Diseases 2019 (COVID-19) as a global pandemic [1]. By then, the disease had surpassed 100 thousand cases over 114 countries, with more than four thousand deaths [2]. One year after the pandemic declaration, the number of the cases continued to increase exceeding 166 million cases with more than 3.5 million deaths as of May 2021 [3]. Since the virus spreads through direct (droplet) and indirect means (contaminated objects and airborne contagion), several behavioral preventive measures should be performed in order to prevent the transmission of the disease [4], [5].

Indonesia is one of the worst COVID-19 affected countries in the Southeast Asian region. In May 2021, the number of COVID-19 cases in Indonesia was the highest among Southeast Asian countries 
reaching 1.7 million cases [6]. The Indonesian Government responded to COVID-19 with several policies aimed at preventing transmission of the disease. Among the policies was include the Large-scale social restriction (PSBB-Pembatasan Sosial Berkala Besar), an equivalent to partial lockdown. In practice, the policy required offices, schools, places of worship and public spaces to close. Transportation capacity within the region was limited, but traditional and modern markets that sold basic needs were left open [7]. During this implementation, any person who had an activity outside their resident had to wear a mask covering nose, mouth and chin. The policy was not implemented in all region of Indonesia, but only cities that met the requirements had to implement the policy. One of the requirements was the number of cases and/or the number of deaths due to the COVID-19 had to be increasing and spreading significantly and rapidly in that region [8].

Jakarta was among the first provinces that implemented the PSBB policy on 10 April 2020. However, some experts criticized the policy for not being effective in maintaining people's COVID-19 prevention behavior nor preventing the increase in number of cases. A study by Suraya et al stated that the cases continued to increase significantly during the implementation of the policy [7]. This ineffectiveness of the policy was caused by the community's lack of compliance with the rules of PSBB [9], [10]. A study by the Indonesian Statistics Agency stated that the lack of sanction towards people who never implemented COVID-19 prevention behaviors was the main reason why many people did not implement the COVID-19 prevention behavior guidelines [11]. This indicates the need for various health promotion programs to be implemented, thereby encouraging and empowering individuals and communities to complying with the COVID-19 prevention behavior protocols.

Health Belief Model (HBM) is one of the most effective widely used models to understand and predict various prevention behaviors [12]. The HBM theory shows that health-related behavior is influenced by people perception of the four variables namely perceived severity, perceived susceptibility, perceived benefit and perceived barrier [13]. Perceived susceptibility is related to an individual's assessment of chances of getting the disease while perceived severity related to the judgment about the seriousness of the diseases. Perceived benefits variable is about the positive things that will happen as a result of the health behavior and perceived barriers is related to the difficulty of adopting the new behavior [14]. A HBM related study in Iran revealed that Self-efficacy, perceived barriers and perceived benefits were the key determinants of COVID19-preventive behaviors among the respondents [15]. A different study in Indonesia showed that perceived severity, perceived benefits, self-efficacy, perceived barriers and cues to action variables were significantly associated with COVID-19 prevention behavior adherence [16]. Another study in Northern Iran revealed that various variables in the Health Belief Model such as perceived barriers, perceived self-efficacy, fatalistic beliefs and perceived interests influenced the COVID-19 preventive behaviors [17]. A similar study in Ethiopia revealed the same pattern where income, perceived barrier, cues to action and self-efficacy were significantly related with the prevention practices against COVID-19 [18]. Although some previous studies were performed using HBM theoretical framework to explore COVID-19 prevention behaviors, similar studies performed in Jakarta, as an epicenter of COVID-19 in Indonesia is less. Therefore, this study aimed at analyzing behavioral factors related with the compliance to the PSBB rules using HBM theoretical framework. This study also used multivariate analysis for determining the most affecting factors related to the COVID-19 preventive behaviors.

\section{RESEARCH METHOD}

This research used quantitative analytics with a cross sectional approach. The population of this research included undergraduate students and the academic and non-academic staff of University of Muhammadiyah Prof. Dr. Hamka located in Jakarta, Indonesia. Data was collected in July 2020, while a convenience non-probability sampling was used as the sampling method. Minimum sample size was calculated using a sample size calculator application by World Health Organization with 95\% Confidence Interval. The minimum sample size was 116 respondents based on the calculation.

Data collection was done using online questionnaire. Prior to filling the questionnaire, the aim and scope of the research and guidance was explained to the respondents. Respondents who agreed to fill out the questionnaire signed the consent form, whereas anonymity and confidentiality of respondents were ensured during research. Ethical clearance was obtained from Health Research Ethical Committee of the University of Muhammadiyah Prof. Dr. Hamka under number 03/20.07/0495.

Instrument of this research consisted of 10 parts. The first part consisted questions related to the characteristics of respondents including age, sex, education and working status. The second part was related to the perceived susceptibility variable with five questions. Perceived susceptibility explored questions about a person's belief that he or she could experience a health condition (COVID-19) based on circumstances or the environment in general. The third part of the questionnaire covered questions about perceived severity. Perceived severity is the belief related to how severe the condition or health condition could be when 
COVID-19 hits him or his family members. The fourth part of the questionnaire included health motivation questions, which consisted of five questions on the Likert scale asking about motivation from one's family and their motivation to stay alive. The fifth part of the questionnaire contained questions about perceived benefits. The perceived benefits question in this study included three questions on a Likert scale that asked about the perceived benefits of complying with the PSBB rules to prevent contraction of COVID 19 and the benefits of maintaining healthy habits.

The sixth part of the questionnaire contained questions about perceived barriers. A perceived barrier is a person's belief that there are things that hinder compliance with PSBB regulations; which could include implementing PSBB. This perceive barrier could be a feeling that implementation of PSBB could lead to reduction of income, wastage of money with the acquisition of bought COVID-19 prevention equipment; interfere with routine activities and the disruption of social relations.

The seventh part included questions about advertising, which consisted of two questions regarding the asking of accessibility to PSBB advertisements. The eighth part asked whether the respondents had attended a seminar or education session that discussed about PSBB. The ninth part covered three questions about access to information related to PSBB that were sourced from social media. The tenth part included questions on compliance with PSBB. This consisted of five questions on a Likert scale asking about a person's ability to comply with the PSBB including the use of masks, physical distancing with others and working and studying from home. The five items of the Likert scale used to identify variables were; strongly agree, agree, neutral, disagree and strongly disagree.

All statistical tests were analyzed using SPSS statistic version 20.0 (IBM Corp., Armonk, NY, USA). Categorization of the measured results was done using the Likert scale for variables, with the mean/median as the cut of point. The analyses performed were univariate, bivariate and multivariate. Univariate analysis provided number and percentage of each variable. Bivariate analysis using the ChiSquare analysis examined the relationship between independent and dependent variables. Variables with a pvalue less than 0.250 were included in the multivariate analysis. Multiple logistic regression in the multivariate analysis for analyzing predictive variables with PSBB compliance behavior as the dependent variable was done.

\section{RESULTS AND DISCUSSION}

This research recruited 116 respondents. Table 1 show that most of respondents were $\leq 25$ years $(62.1 \%)$, female $(77.6 \%)$ and had senior high school education $(62.1 \%)$. Most of the respondents were undergraduate students $(62.1 \%)$.

Table 1. Respondents' demographic characteristic

\begin{tabular}{lcc}
\hline \multicolumn{1}{c}{ Characteristic } & $\mathrm{n}$ & $\%$ \\
\hline Age (in years) & & \\
$\quad>25$ & 44 & 37.9 \\
$\quad \leq 25$ & 72 & 62.1 \\
Gender & & \\
$\quad$ Female & 90 & 77.6 \\
$\quad$ Male & 26 & 22.4 \\
$\quad$ Education & & \\
$\quad$ University degree & 44 & 37.9 \\
$\quad$ Senior high school & 72 & 62.1 \\
$\quad$ Working status & & \\
$\quad$ Academic/nonacademic staff & 44 & 37.9 \\
$\quad$ Undergraduate student & 72 & 62.1 \\
\hline
\end{tabular}

Table 2 shows respondents' COVID-19 prevention behavior compliance and its determining factors. Results showed that more than $60 \%$ of respondents had good COVID-19 prevention behavior (61.2\%). Half of the respondents (50.9\%) had less perceived susceptible (beliefs about the likelihood of getting COVID-19), less perceived severity (78.4\%), less health motivation (50.9\%), more likely perceived benefit (70.7\%) and less perceived barrier $(54.3 \%)$. In cues to action variables, more than half of respondents got information related to PSBB policy from television (65.5\%), education/seminar program $(60.3 \%)$ and social media $(53.4 \%)$.

Table 3 shows that there was no significant difference related to COVID-19 prevention compliance behavior based on the socio-demographic characteristics of respondents. There was a significant relationship between PSBB compliance behavior with health motivation (p-value 0.001), perceived benefit (p-value 0.008) and perceived barrier (p-value 0.007) but there was no significant relationship between COVID-19 prevention behavior, with the perception of susceptibility (p-value 0.096) and perceived severity (p-value 0.215). 
Table 2. COVID-19 prevention behavior and its determinants based on Health Belief Model

\begin{tabular}{lcc}
\hline & $\mathrm{n}$ & $\mathbf{\%}$ \\
\hline COVID-19 preventive behavior & & \\
$\quad$ Good & 71 & 61.2 \\
$\quad$ Poor & 45 & 38.8 \\
Perceived susceptibility & & \\
$\quad$ More susceptible & 57 & 49.1 \\
$\quad$ Less susceptible & 59 & 50.9 \\
Perceived severity & & \\
$\quad$ More severe & 25 & 21.6 \\
$\quad$ Less severe & 91 & 78.4 \\
Health motivation & & \\
$\quad$ More & 57 & 49.1 \\
$\quad$ Less & 59 & 50.9 \\
Perceived benefit & & \\
$\quad$ More likely & 82 & 70.7 \\
$\quad$ Less likely & 34 & 29.3 \\
Perceived barrier & & \\
$\quad$ Less & 63 & 54.3 \\
$\quad$ More & 53 & 45.7 \\
Cues to action (The source of information related to PSBB) & & \\
Television & & \\
$\quad$ Yes & 76 & 65.5 \\
$\quad$ No & 40 & 34.5 \\
Educational session & & \\
$\quad$ Yes & 46 & 39.7 \\
$\quad$ No & 70 & 60.3 \\
Social media & & \\
$\quad$ Yes & 62 & 53.4 \\
$\quad$ No & 54 & 46.6 \\
\hline & & \\
\hline
\end{tabular}

Table 3. Bivariate analysis of factors related to COVID-19 prevention behavior

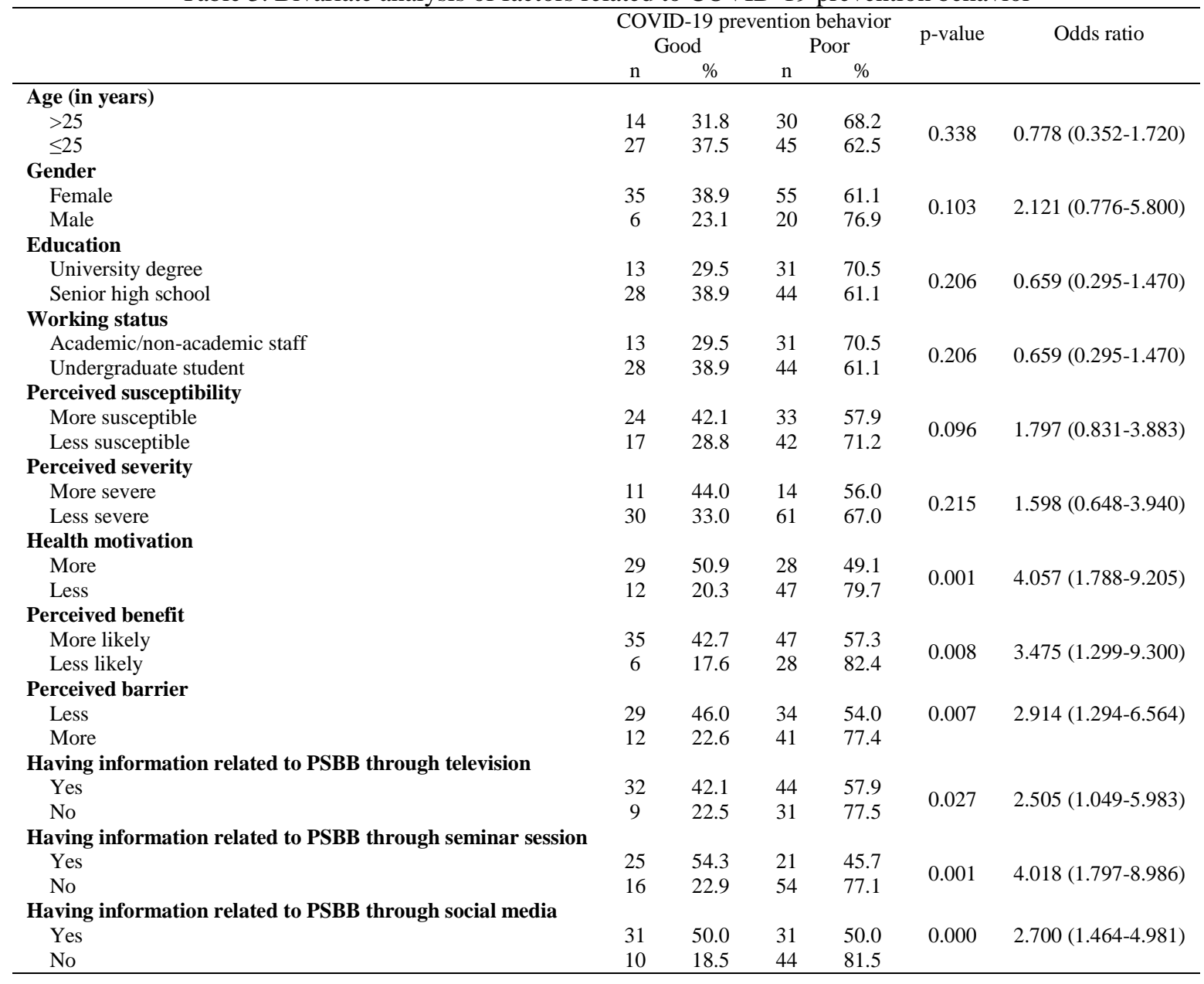


The results show that respondents who had more health motivational were 4.057 times more likely to have good COVID-19 prevention behavior compared to respondents who had less health motivational (95\% CI; OR 1.788-9.205). Respondents who had more perception of benefits were 3.475 times more likely to have good COVID-19 prevention behavior compared to respondents who had less (low) perception of benefits (95\% CI; OR 1.299-9.300). Meanwhile, respondents who had less perceived barriers were 2.914 times more likely to have good COVID-19 prevention behavior compared those who had more perceived barriers (95\% CI; OR 1.294-6.564).

There was a significant relationship between PSBB compliance behavior and having information related to PSBB from advertising (p-value 0.027), seminar/educational session (p-value 0.001) and social media (p-value 0.000). Respondents who had accessed information related to PSBB from the various media (television, educational/seminar session and social media) tended to have good COVID-19 prevention behavior. Respondents who had accessed information related to PSBB from television had 2.505 times better COVID-19 prevention behavior compared to those who had not (95\% CI; OR 1.049-5.983).

Table 4 shows multivariate analysis result. The table reveals that health motivation and perceived benefits positively affected COVID-19 prevention behavior. Respondents with good motivational health had a 5.471 times better COVID-19 prevention behavior than those who did not have (95\% CI; OR 2.04814.619). Moreover, respondents who felt benefits from implementing COVID-19 prevention behavior had 3,314 times chances in having good COVID-19 prevention behavior compared to respondents who did not feel the same (95\% CI; OR 1.184-9.274).

Table 4. Multivariate analysis of COVID-19 preventive behavior

\begin{tabular}{|c|c|c|c|c|c|c|}
\hline & \multirow{2}{*}{ B } & \multirow{2}{*}{ SE } & \multirow{2}{*}{ Sig } & \multirow{2}{*}{$\operatorname{Exp}(B)$} & \multicolumn{2}{|c|}{$95 \%$ CI } \\
\hline & & & & & Lower & Upper \\
\hline Gender & -0.617 & 0.623 & 0.322 & 0.540 & 0.159 & 1.828 \\
\hline Education & -0.219 & 1.583 & 0.890 & 0.803 & 0.036 & 17.871 \\
\hline Working status & 0.941 & 1.595 & 0.556 & 2.561 & 0.112 & 58.417 \\
\hline Perceived susceptibility & -0.631 & 0.501 & 0.208 & 0.532 & 0.200 & 1.420 \\
\hline Perceived severity & 0.850 & 0.623 & 0.173 & 2.339 & 0.690 & 7.933 \\
\hline Health motivation & 1.700 & 0.501 & 0.001 & 5.471 & 2.048 & 14.619 \\
\hline Perceived benefit & 1.198 & 0.525 & 0.022 & 3.314 & 1.184 & 9.274 \\
\hline Perceived barrier & 0.272 & 0.536 & 0.612 & 1.313 & 0.459 & 3.754 \\
\hline See advertisement & 0.969 & 0.517 & 0.061 & 2.634 & 0.956 & 7.258 \\
\hline Having seminar & 0.874 & 0.557 & 0.117 & 2.395 & 0.803 & 7.142 \\
\hline Getting info from social media & 0.009 & 0.498 & 0.986 & 1.009 & 0.380 & 2.677 \\
\hline Constant & -8.844 & 2.196 & 0.000 & 0.000 & & \\
\hline
\end{tabular}

\section{DISCUSSION}

The results of this study show that approximately $65 \%$ of respondents have a good behavior related to the prevention of COVID-19. A study by Indonesian Statistics Agency also showed a similar pattern where about $67 \%$ of respondents who comply with the COVID-19 preventive behaviors [19]. This study showed that health motivation positively influenced COVID-19 prevention behavior. A previous study in Hormozgan Iran alsho found that protection motivation was positively associated with the COVID-19 preventive behaviors [20]. Various theories have identified different COVID19 prevention behavior related factors, among which is the Protection Motivation Theory (PMT) [20] which is often used to predict protective behavior. The PMT believes that personal motivation to protect oneself is the reason a person adopts a protective behavior against health threats [21]. Various factors like confidence in institutions, social experiences, knowledge, one's mental health and well-being could increase motivation [22]. Knowledge and exposure to information about the risk of contracting COVID-19 could increase a person's motivation and capability to comply with protective behavior. It is also strongly influenced by social norms [23].

However, the government has an important role in increasing people's motivation so as to comply with COVID-19 prevention behavior through trust and confidence towards the government. This could be realized by ensuring and teaching citizens the effectiveness and necessity of the prepared guidelines [24]. Various efforts have been made by the government in different forms to implement the COVID-19 prevention and control strategy in Indonesia. As stipulated in the Ministry of Health regulations, there are at least seven main strategies [25], among which those that play a very important role in shaping motivation are the implementation of risk communication and community empowerment.

The government, both at the central and regional levels enforced these efforts through various methods and media. The Indonesian government focused on risk communication strategies to increase public awareness of COVID-19. This strategy is carried out using various methods and media, both digital and

Int J Public Health Sci, Vol. 22, No. 1, March 2022: 20-27 
conventional media [26]. The government's policy regarding the COVID-19 preventing behavior in Indonesia is regulated by the Decree from the Indonesian Minister of Health concerning Health Protocols for the Community in Public Places and Facilities. The policy regulates and invites everyone to start implementing the new behavioral habits as a form of adaptation to the pandemic [27]. The two main public policies set by the government were physical distancing and minimizing mobility [28]. A previous study revealed that several activities imposed by the government during the COVID-19 pandemic could help for behavioural change [16].

Respondents who get exposure to information related to PSBB have higher chances of having good COVID-19 prevention behaviour compared to respondents who do not get a similar exposure. A previous study in Bangladesh also showed that people with higher knowledge revealed higher performing COVID-19 preventive behaviours [29]. Online seminars are the right health promotion methods to be used in spreading and obtaining knowledge about efforts to deal with COVID-19 and creating perceptions about the new normal, especially among groups that use information from seminars as their prior knowledge [30]. Communication efforts should be made to establish public awareness. Developing and disseminating information regarding COVID-19 to the key stakeholders and the at-risk groups that are accessible to everyone with including those with different abilities and in local languages through mass media (including digital media, radio, broadcast message and other channels) are among activities that need to be done [31]. The WHO stated that health education as a tool for health promotion was critical for the improvement of the health of populations and promotion of health capital. Health education is the development of an individual, group, institutional, community and the systemic strategies to improve their health knowledge, attitudes, skills and behavior. The primary objective of health education is to influence individuals and community health behavior, as well as their living and working conditions that affect their health [32]. This principle is what makes it possible for people exposed to counseling tending to behave obediently with COVID-19 prevention behavior.

\section{CONCLUSION}

Most variables in the Health Belief Model framework (such as health motivation, perceived benefits, perceived barriers and cues to action variable) positively influenced COVID-19 prevention behavior among respondents. Dissemination of health information particularly related to COVID-19 prevenion through various media (both print and digital media) needed to continue so that there is increased motivation towards healthy living and increased understanding of the benefits of observing COVID-19 prevention behaviors. In addition, health education related to COVID-19 prevention should continue to be carried out by emphasizing the message that COVID-19 prevention activities are not an obstacle to people's lives and that COVID-19 prevention activities such as physical distancing, wearing a mask and washing hands using soap are easy things carried out in the daily lives of the community.

\section{ACKNOWLEDGEMENTS}

We extend our gratitude to the Health Research and Development Agency of the University of Muhammadiyah Prof. Dr. Hamka for its funding of the entire process of this research.

\section{REFERENCES}

[1] C. D and V. M, "WHO declares COVID-19 a pandemic," Acta Bio-Medica : Atenei Parmensis, vol. 91, no. 1, pp. 157-160, 2020, doi: 10.23750/ABM.V91I1.9397.

[2] WHO, "WHO Director-General's opening remarks at the media briefing on COVID-19." 11 March 2020. https://www.who.int/director-general/speeches/detail/who-director-general-s-opening-remarks-at-the-media-briefing-on-covid-19--11-march-2020. (accessed Oct. 05, 2021).

[3] WHO, "WHO Coronavirus (COVID-19) Dashboard.” 2021. https://covid19.who.int/table (accessed Oct. 12, 2021).

[4] M. Lotfi, M. R. Hamblin, and N. Rezaei, "COVID-19: Transmission, prevention, and potential therapeutic opportunities," Clinica Chimica Acta; International Journal of Clinical Chemistry, vol. 508, pp. 254-266, Sep. 2020, doi: 10.1016/j.cca.2020.05.044.

[5] I. Ahmed et al., "Behavioral preventive measures and the use of medicines and herbal products among the public in response to COVID-19 in Bangladesh: A cross-sectional study," PloS one, vol. 15, no. 12, pp. e0243706--e0243706, Dec. 2020, doi: 10.1371/journal.pone.0243706.

[6] Center for Strategic and International Studies, "Southeast Asia COVID-19 Tracker." 2021. https://www.csis.org/programs/southeast-asia-program/projects/southeast-asia-covid-19-tracker (accessed May 24, 2021).

[7] I. Suraya, M. I. Nurmansyah, E. Rachmawati, B. Al Aufa, and I. I. Koire, "The impact of large-scale social restriction on COVID19 Incidence: a case study of four regions in Indonesia," Kesmas: National Public Health Journal, vol. 15, no. 2, 2020, doi: 10.21109/kesmas.v15i2.3990.

[8] Ministry of Health Republic of Indonesia, "Guidelines for large-scale restrictions in the context of accelerating handling of coronavirus disease 2019 (COVID-19)," 2020. https://peraturan.bpk.go.id/Home/Details/135220/permenkes-no-9-tahun-2020 (accessed Oct. 12, 2021).

[9] Meilinda Triana Pangaribuan and Adis Imam Munandar, "DKI Jakarta Government's policy in handling the COVID-19 pandemic," GOVERNMENT : Jurnal Ilmu Pemerintahan, vol. 14, no. 1, pp. 1-9, 2021.

[10] E. Michelle, K. Betarli Lengkong, and M. Jusuf, "Community compliance and obedience to the transitional period PSBB regulations based on the governor's regulation No. 88 of 2020 in the West Jakarta Region," ADIL: Jurnal Hukum, vol. 11, no. 2, 
2020, doi: 10.33476/ajl.v11i2.1654.

[11] Tim BPS COVID-19 Statistical Task Force, "Results of the community behavior survey during the COVID-19 pandemic (7-14 September 2020)," in Community Behavior During the COVID-19 Pandemic, vol. 19, no. September, Jakarta: BPS RI, 2020 , pp. 1-50.

[12] C. Li, Y. Liu, D. Xue, and C. W. H. Chan, "Effects of nurse-led interventions on early detection of cancer: A systematic review and meta-analysis," International Journal of Nursing Studies, vol. 110, p. 103684, 2020, doi: 10.1016/j.ijnurstu.2020.103684.

[13] J. M. Samet, S.-Y. Yoon, W. H. Organization, and others, "Gender, women, and the tobacco epidemic/edited by Jonathan M. Samet and Soon-Young Yoon," in Gender, women, and the tobacco epidemicledited by Jonathan M. Samet and Soon-Young Yoon, World Health Organization, 2010.

[14] R. Orji, J. Vassileva, and R. Mandryk, "Towards an effective health interventions design: an extension of the health belief model," Online Journal of Public Health Informatics, vol. 4, no. 3, 2012, doi: 10.5210/ojphi.v4i3.4321.

[15] A. Mirzaei, F. Kazembeigi, H. Kakaei, M. Jalilian, S. Mazloomi, and H. Nourmoradi, "Application of health belief model to predict COVID-19-preventive behaviors among a sample of Iranian adult population," Journal of Education and Health Promotion, vol. 10, p. 69, Feb. 2021, doi: 10.4103/jehp.jehp_747_20.

[16] R. Jose, M. Narendran, A. Bindu, N. Beevi, M. L, and P. V Benny, "Public perception and preparedness for the pandemic COVID 19: A Health Belief Model approach," Clinical Epidemiology and Global Health, vol. 9, pp. 41-46, 2021, doi: 10.1016/j.cegh.2020.06.009.

[17] H. Shahnazi, M. Ahmadi-Livani, B. Pahlavanzadeh, A. Rajabi, M. S. Hamrah, and A. Charkazi, "Assessing preventive health behaviors from COVID-19: a cross sectional study with health belief model in Golestan Province, Northern of Iran," Infectious Diseases of Poverty, vol. 9, no. 1, p. 157, Nov. 2020, doi: 10.1186/s40249-020-00776-2.

[18] T. Tadesse, T. Alemu, G. Amogne, G. Endazenaw, and E. Mamo, "Predictors of coronavirus disease 2019 (COVID-19) Prevention practices using health belief model among employees in Addis Ababa, Ethiopia, 2020," Infection and Drug Resistance, vol. 13, pp. 3751-3761, Oct. 2020, doi: 10.2147/IDR.S275933.

[19] BPS-Statistics Indonesia, Community behavior during emergency PPKM. Jakarta: Badan Pusat Statistik, 2021.

[20] R. Ezati Rad et al., "Application of the protection motivation theory for predicting COVID-19 preventive behaviors in Hormozgan, Iran: a cross-sectional study," BMC Public Health, vol. 21, no. 1, p. 466, Mar. 2021, doi: 10.1186/s12889-021-10500-w.

[21] R. W. Rogers, "A Protection Motivation Theory of Fear Appeals and Attitude Change1," The Journal of Psychology, vol. 91, no. 1, pp. 93-114, 1975, doi: 10.1080/00223980.1975.9915803.

[22] L. Wright, A. Steptoe, and D. Fancourt, "Predictors of self-reported adherence to COVID-19 guidelines. A longitudinal observational study of 51,600 UK adults," The Lancet Regional Health. Europe, vol. 4, p. 100061, May 2021, doi: 10.1016/j.lanepe.2021.100061

[23] K. Keizer, S. Lindenberg, and L. Steg, “The spreading of disorder," Science, vol. 322, no. 5908, pp. 1681-1685, 2008, doi: 10.1126/science.1161405.

[24] J. J. V. Bavel et al., "Using social and behavioural science to support COVID-19 pandemic response," Nature Human Behaviour, vol. 4, no. 5, pp. 460-471, May 2020, doi: 10.1038/s41562-020-0884-Z.

[25] Menteri Kesehatan Republik Indonesia, "Decree of the Minister of Health of the Republic of Indonesia Number HK.01.07/MenKes/413/2020 concerning Guidelines for the Prevention and Control of Corona Virus Disease 2019 (COVID-19) (In Indonesia: Keputusan Menteri Kesehatan Republik Indonesia Nomor HK.01.07/MenKes/413/2020 tentang Pedoman Pencegahan dan Pengendalian Penyakit Corona Virus Disease 2019 (COVID-19)," 2020.

[26] WHO, "Stakeholder review of Indonesia's Operational Response Plan COVID-19." 2020. https://www.who.int/indonesia/news/detail/27-07-2020-stakeholder-review-of-indonesia-s-operational-response-plan-covid-19 (accessed Oct. 12, 2021).

[27] Ministry of Health of Indonesia, "Guidelines for the prevention and control of corona virus disease 2019 (COVID-19)." 2020. https://covid19.go.id/p/protokol/pedoman-pencegahan-dan-pengendalian-coronavirus-disease-covid-19-revisi-ke-5 (accessed Aug. 01, 2021).

[28] Muhyiddin and D. Wardhana, "Editorial Note," Indones. J. Dev. Planning2, vol. 4, no. 1, 2020.

[29] I. Hosen, A. H. Pakpour, N. Sakib, N. Hussain, F. Al Mamun, and M. A. Mamun, "Knowledge and preventive behaviors regarding COVID-19 in Bangladesh: A nationwide distribution," PloS one, vol. 16, no. 5, pp. e0251151-e0251151, May 2021, doi: 10.1371/journal.pone.0251151.

[30] M. Fadilah, W. I. F. Ningsih, O. Berlin, A. Wimaulia, A. Azlin, and R. A. Syakurah, "The effect of online seminars on knowledge in increasing immunity to face COVID-19 and perceptions of the new normal in community," J-KESMAS: Jurnal Kesehatan Masyarakat, vol. 6, no. 2, p. 134, 2021, doi: 10.35329/jkesmas.v6i2.1877.

[31] UNSDG, "Indonesia multi-sectoral response plan to COVID-19." 2020. https://unsdg.un.org/resources/indonesia-multi-sectoralresponse-plan-covid-19 (accessed Oct. 12, 2021).

[32] WHO, "Health education: theoretical concepts, effective strategies and core competencies: A foundation document to guide capacity development of health educators.” 2012. https://apps.who.int/iris/handle/10665/119953 (accessed Jul. 20, 2021).

\section{BIOGRAPHIES OF AUTHORS}

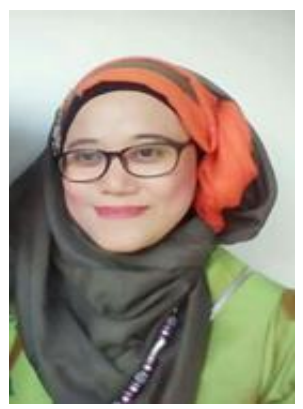

Hidayati (D) SC SC $\mathrm{P}$ is a lecturer at Muhammadiyah University Prof. DR. HAMKA (UHAMKA) Jakarta. She is also member of the administrative board at the Indonesia Society for Health Promotor an Educator.She interested in exploring social determinants of health and wellbeing particularly among elderly. She is also actively involved in the Health Council of Muhammadiyah, Indonesian socio-religious organization for performing projects in the field of community empowerment and health promotion in the Islamic Boarding School. She can be contacted at email hidayati@uhmka.ac.id. 


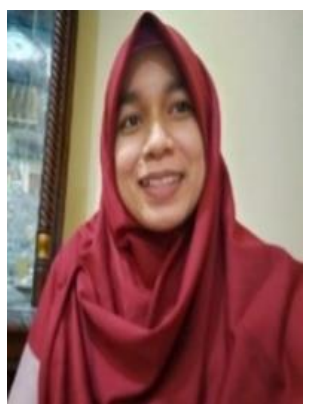

Nia Musniati (D) SII SC P is an epidemiologist/health statistician who works as a lecturer at the Public Health Study Program, Faculty of Health Sciences, Universitas Muhammadiyah Prof. Dr. HAMKA Jakarta, Indonesia. She is the editor of an accredited national journal, ARKESMAS (Arsip Kesehatan Masyarakat), and Editor of the Journal of Community Service, namely ARDIMAS: Jurnal Arsip Pengabdian Masyarakat. She interested in exploring the determinants of health, health behavior, and adolescent health in urban areas. She can be contacted at email: niamusniati@uhamka.ac.id.

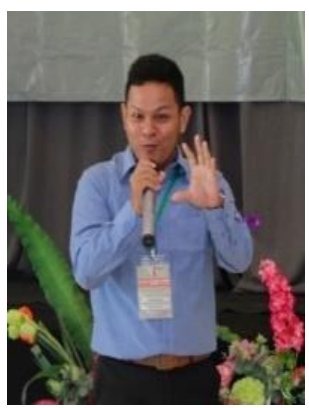

Ahmad Hidayat (D) 81 SC P is a lecturer and researcher at the Faculty of Public Health, Andalas University, Indonesia. He works in the Department of Health Promotion and has interests in issues related marginalized community, physical activity, non-communicable diseases, and community empowerment. He is active in writing in the mass media related to health literacy, especially during the COVID-19 pandemic. He can be reached at email: ahmadhidayat@ph.unand.ac.id.

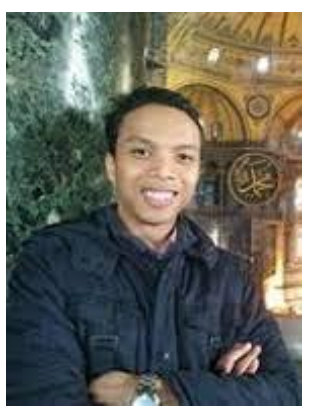

Mochamad Iqbal Nurmansyah (D) SC P is a research assistant at Public Health Department, Faculty of Health Sciences, Universitas Islam Negeri Jakarta Syarif Hidayatullah Jakarta, Indonesia. Involved with various research projects in the field of social determinants of health, health behavior and healthcare policy and management. Active member of the Indonesian Public Health Association. He can be contacted at: iqbalnurmansyah@uinjkt.ac.id. 